\title{
WORKING AT SANBORNS: GENDER, PATERNALISM, AND UNION MOVEMENT (1920-1948)
}

\author{
TRABAJANDO EN SANBORNS: \\ GÉNERO, PATERNALISMO Y MOVIMIENTO SINDICAL (1920-1948)
}

\author{
Kevin M. Chrisman \\ York University \\ Canada \\ kevinmichaelchrisman@gmail.com
}

\begin{abstract}
Between 1920 and 1948, Sanborns developed into Mexico's most prestigious social institution. As the business evolved from a drugstore into a modern department store, the owners hired a predominantly female workforce to cater to visiting customers. This work explores how Sanborns adopted a paternalistic labor system and gendered hierarchy over its workforce. Women workers rejected this paternalism, motivated by eruptions of outside organizations, fellow employees, and visiting customers. Workingwomen at Sanborns navigated around gender, race, and class divisions during their work routines. This work observes how precarious labor conditions at Sanborns led to labor movements directed against the store management.
\end{abstract}

Keywords: Sanborns, working-women, paternalism, gender, protests.

\section{Resumen}

Entre 1920 y 1948 Sanborns se convirtió en la institución social mexicana más prestigiosa. A medida que el negocio evolucionó de una farmacia a una moderna tienda departamental, los propietarios contrataron una fuerza de trabajo predominantemente femenina para atender a los clientes. Este trabajo explora cómo Sanborns adoptó un sistema paternalista y una jerarquía de género sobre su mano de obra. Las obreras rechazaron este paternalismo, motivadas por las irrupciones de organizaciones externas, compañeros de trabajo y clientes; sorteaban divisiones de género, raza y clase durante sus jornadas. Este trabajo observa cómo las precarias condiciones laborales condujeron a movimientos laborales.

Palabras clave: Sanborns, obreras, paternalismo, género, protestas. 
Walter and Frank Sanborn, the two brothers from California that established the Sanborns American Pharmacy in 1903, had built a formidable reputation for themselves among elite circles. Upper-class Mexicans and visiting tourists of Mexico had made going to Sanborns a part of everyday life in downtown Mexico City. As Sanborns continued its commercial expansion and rise in popularity, the store owners eventually moved into what became their flagship location inside the beautiful Casa de los Azulejos, one of Mexico City's most recognizable landmarks. The 1919 inauguration of Sanborns in the House of Tiles cemented the institution as one of the most prestigious rendezvous for Mexico City's high society. The new-look department store could accommodate hundreds of dining guests within the downstairs restaurant and upstairs banquet hall (AHCM, 1921).

In September 1922, The American Chamber of Commerce organized a banquet held at Sanborns. The meeting addressed topics related to import duties, tax remissions, the Mexican economy, and labor relations. Frank Sanborn gave a speech and spoke as an authority on the responsibilities of U.S. merchants operating in Mexico. He told the audience that he felt proud of the 300 workers under his management. According to Sanborn, the company kept $95 \%$ of its workforce per year, and boasted having two original employees from their payroll 20 years ago. The key to his success in retaining workers involved instilling the concepts of "honesty and loyalty", which, according to Sanborn, were "the only two qualities we demand to have enough capacity to develop" in their workers. Sanborn went on to describe his methodology that ensured a disciplined workforce. Workers needed to be happy. If not, the company transferred them into other departments. Once moved, if the managers determined that "their character" still made them "discontent", then the company would fire them. Sanborn stressed that beyond anything, worker loyalty to the company determined his overall success. "For me, my boys and girls are my own re- sponsibility. When they are careless, I scold them and when they do well, I praise them. I love them and do not feel ashamed that they know that (Anonymous: 1922b)". Frank Sanborn's candid speech to the Chamber revealed his company's labor paternalism that treated Mexican employees as children in need of paternal guidance and discipline. Sanborn believed this paternalism was necessary to create a disciplined and loyal workforce. As noted by Michael Snodgrass, this social viewpoint and business practice typified how many industrial leaders in the nineteenth viewed their employees (Snodgrass, 2003: 62).

Throughout its 118-year history, Sanborns provided ample job opportunities for young working-class Mexican women. A predominantly female workforce carried out the store's daily operations. Women waitresses served customers in the restaurant and at the soda fountain; women worked as secretaries inside the offices, behind the sales counters, and in the kitchen; they also worked as floor managers, vendors, and assistants of the various store departments.

The goal in this article is to plot workingclass women into the history of Sanborns by examining the interactions and relationships they shared with company management, visiting customers, and organized labor. By using government reports, census data, labor statistics, company ephemera, court records, periodicals, oral interviews, and company documents, this article highlights the labor experiences of working women at Sanborns stores in Mexico City and Monterrey, Nuevo León between 1920-1948. It argues that Sanborns, like many U.S.-owned businesses in Latin America, adopted a paternalistic labor system in managing its Mexican workforce. A gendered hierarchy further subordinated working-women under Sanborns's upper management who were white U.S.-born citizens. Women workers, however, often rejected this paternalism (with greater or less success), sometimes motivated by the eruptions of outside independent labor unions, fellow workers, and visiting customers in their workspaces. 
Sanborns directors in Mexico City and Monterrey responded by transferring disloyal or unhappy employees to different store departments or by simply firing them all together. Evolving with postrevolutionary Mexico's changing economic conditions, cultural production, and nationalistic trends, Sanborns owners thoroughly Mexicanized their store to increase their customer base beyond local elites and to promote foreign tourism. In the 1930s, a new folkloric Sanborns waitress uniform combined a selective appropriation of gendered clothing worn by Mexico's indigenous populations. These uniforms further integrated working women under the company's paternalism. It subjected them to perform their duties at work while their bodies displayed a romanticized stereotype of Mexico's indigenous past. In the 1940s, a Sanborns company-controlled union further weakened labor protections for employees and provided another layer of control for store owners. These labor policies ultimately failed, however, because they created tensions among workers who felt increasingly vulnerable about their job security.

This is a story about the labor experiences of women in the service and retail sector in Mexico City and Monterrey. It contributes to an understanding of the relationship between gender and class within the lived experience of Mexico's working-class women (Hernández, 2017; Palacios, 2017; Porter, 2003; Fernández-Aceves, 2003; Lear, 2001). Focusing on Sanborns extends the historiography by including narratives from non-industrial workspaces in Mexico City and Monterrey. Gender historians have revealed how shifting public perceptions on gender, class, and the economy have shaped workforces and industrial paternalism (Farnsworth-Alvear, 2000; Lobato, 1997; Weinstein, 1996; Wolfe, 1993). For example, factories were considered inherently masculine spaces, though with some notable exceptions (mainly in the textile industries). In Mexico, this was generally associated with jobs in manufacturing, industrial processing, and agriculture (Porter, 2003).
Susie Porter analyzed the relationship between working women, discourses on morality and honor, and Mexico's rapid industrialization, revealing that women worked primarily in Mexico's cigarette and clothing industries. Mexican government administrators, led by Porfirio Díaz, turned to foreign investors from Europe and the United States to help stimulate a stagnating economy. By the turn of the century, favorable economic conditions led to expanding industrial production and an increase in mixed-sex urban factories. Interestingly, Porter notes how women's work habits, consumption, and socializing "brought them into factories and public places in new ways" (Porter, 2003: $x v)$. In the 1920s, Sanborns was considered a mixed-sex environment, and a popular space for elite sociability where Mexicans performed their identities and flaunted their wealth and power to one another. Working women at Sanborns played an integral role in defining these class identities. Their gender, physical appearance of their uniforms, and subordinate workplace positions became visual markers used by social critics and Sanborns directors to describe conceptions of modernity, sociability, and consumption in Mexico. My research shows that Sanborns stores are essential sites for understanding how U.S.-style consumer capitalism shaped everyday life and work within Mexico's urban environments.

María Teresa Fernández-Aceves's (2003) analysis of female tortilla workers shows that the mechanization of corn mills in Guadalajara favored male employees over their female counterparts. Working women mobilized in unions and carved out political space for themselves by contesting gendered notions of female domesticity and motherhood enforced by the state, mill owners, and male workers. FernándezAceves challenges contending notions in labor histories viewing the labor movement as dominated by male actors, revealing the active participation of women in labor mobilization (Fernández-Aceves, 2003: 81-82). Her work also joins conversation with recent Latin American labor histories exami- 
ning how changing cultural understandings of gender shaped how people understood industrial workplaces (Farnsworth-Alvear, 2000). The general cultural understanding of women's relationship to men in Mexico may have influenced the decision-making by Sanborns managers to hire predominantly low-wage earning female workforce.

My story about working women at Sanborns in Mexico City and Monterrey reveals how gender and class differences between sexes created tensions among workers and in union movement (Fernández-Aceves, 2003: 82). In the 1920s, unionized male bakers in Mexico City mobilized and symbolically protested against Sanborns for deliberately hiring non-unionized women workers who earned significantly less wages. The bakers viewed these labor practices as threats against their very livelihoods. In the 1940s, working women at Sanborns Monterrey resisted the company's paternalism. Women workers played an active role in labor mobilization by deciding when to go on strike, and by filing lawsuits against the company in order to improve their labor conditions. Similar to Sonia Hernández's (2017: 176) work on women tobacco workers in Nuevo León, my work challenges inscribed notions that labor activism in Monterrey was inherently masculine. However, similarly to Fernández-Aceves's conclusions, Monterrey's labor inspectors, government arbitrators, union leaders, and company lawyers who oversaw union arbitration were all men, showing that working women at Sanborns remained marginalized by male decision makers (Fernández-Aceves, 2003: 83).

Paternalism is often defined by historians as a managerial style based on the image of a fatherly figure that provided necessities to workers while simultaneously depriving them of their independence (Dowd Hall et al., 1987: xvii). This system of industrial relations extended workers non-wage incentives in order to create a regimented and docile workforce loyal to company objectives (Snodgrass, 2003: 54). It also attempted to hinder and dissuade workers from the presence of outside labor organizations, which by the 1920s was making significant inroads across Latin America. Labor historians of Mexico have described how paternalism took on different forms and meanings, shaped in part by large-scale processes like industrialization, prevailing ideological currents on class and gender, regionalism, and Revolution. (Porter, 2003; Gauss, 2010; Palacios Hernández, 2017; Snodgrass, 2003; Ramírez Sánchez, 2011; Vellinga, 1979). Michael Snodgrass found both similarities and important differences between the industrial paternalism found in Monterrey and the rest of the industrialized world. His comparative study of Monterrey's largest companies, including the Cuauhtémoc Brewery, spotlights how Monterrey's industrial paternalism was "punctuated by benevolence, patriarchy, and personalism”. His study untangles local union activity, the changing positions of Monterrey's industrialists to national labor movements and extends the labor historiography beyond the Cárdenas years. Snodgrass regretted that his study ignored some workers, including retail clerks, "whose voices remain muted in the archive". This article answers his call to unmute some of the voices and experiences of working-class retail workers in Mexico.

Sanborns's company paternalism shares similar characteristics to the "distinctly personalized style" of industrial paternalism at the brewery analyzed by Snodgrass (Snodgrass, 2003: 54-62). Sanborns was a family-owned and operated company. The directors protected the company's structure from the potentially harmful influences of revolutionary union organizing that followed the Mexican Revolution by placing family members and other U.S. citizens in top managerial positions. The development of Sanborns paternalism was likely influenced by the company owner's intimate role within the store's daily operations. Sanborns directors preemptively organized their own workforce in the context of the pro-union national climate of the 1930s1940s. The Union of Employees of Sanborns Monterrey, a company-controlled union (referred to as a sindicato blanco) helped the 
company maintain their paternalistic system of management at their new branch store in Monterrey. However, the archives do not provide details regarding the company union's origins, organization, or membership size. Whether in fact Sanborns had a single union in Mexico or whether separate unions represented workers in Mexico City and Nuevo León remains unclear. Further, only fragments of details exist regarding the extent of the union's non-wage provisions provided to employees prior to the 1960s.

Researching Mexico's private sector using public archives offers inherent challenges for historians. Corporations like Walgreen's Company (1946-1985) and Grupo Carso (1985-present) -the former and current owners of Sanborns who collectively owned the company for the past 75 yearsgenerally do not grant investigators access to their sensitive business data. When Walgreens sold Sanborns to Grupo Carso in 1985, business directors determined that any archival material pertaining to their 39year ownership was a closed chapter in their company's past. Unfortunately, any documentation the company may have held was likely discarded. Thus, this article contains very limited information related to Walgreens and their influence on Sanborns's labor policies in the mid-1940s. Evidence collected for this article centers around two distinct labor conflicts that occurred at Sanborns stores in Mexico City (1922), and Monterrey (1947). My historical approach and choice of periodization were largely determined by the availability of archival material at my disposal. This article stems from a much broader historical synthesis about the cultural history of Sanborns that I wrote for my first project (Chrisman, 2018).

\section{Working Women at Sanborns}

In 1919, Sanborns expanded beyond its modest origins as a U.S.-style drugstore into a modern department store and high-class restaurant. Company owners hired working-class Mexican women to serve the large crowds that visited Sanborns seven days a week from 8:00am to 10:00pm (Anonymous, 1921a). Women catered some of the most powerful people in Mexico City's upper-class. This included bankers, industrialists, foreign dignitaries, politicians, military officers, intellectuals, journalists, celebrities, and foreign tourists (Anonymous, 1924: 35). The Mexican journalist Agustín Barrios Gómez observed, "there was no important man in Mexico who had not had coffee in Sanborns" (Barrios Gómez, 1994: 5-A). Women workers at Sanborns served as important facilitators that provided the company's main interaction with visiting customers. Waitresses developed working relationships with their guests, and customers often went to Sanborns specifically to dine in the section of their favorite waitress. As historian Michael Snodgrass observes, having a stable income and job security was important for working women; other jobs within the retail sector probably existed elsewhere, but having a chance to work for a reputable company probably made women workers feel honorable and gave them a sense of pride (Snodgrass, 2003: 75-76). The notoriety of Sanborns may have drawn women to try and work there for their own reasons. The Mexican writer Andrés Henestrosa recalled that during the 1920s-1930s, there were ample job opportunities for young women at Sanborns. As a frequent customer who ate breakfast at Sanborns, he remembered women working as counter assistants that were "able to leave their houses and show off their clothes” (Zarebska, 1999: 136).

At Sanborns, a set hierarchy existed in the workspaces that separated unskilled Mexican workers from the company's upper management. The family-owned business tapped Sanborn relatives to fill top executive positions and hired almost exclusively white Americans as the store managers. Floor supervisors oversaw workers divided within each store department. Men and women held these managerial positions, some of whom were U.S. citizens. However, Sanborns also hired Mexican women as floor supervisors and secretaries, suggest- 
ing that some upward mobility in the company was possible. For example, a company brochure from 1939 dedicated a page to the nine store supervisors at Sanborns that included Marie Guzman, Frank Sanborn's private secretary, and Refugio Muciño, the perfume department manager. Captions for the women highlighted their continued loyalty working at Sanborns; Guzman started in 1921, and Muciño in 1922 (ASH, 1939).

By 1921, Sanborns employed a far greater number of waitresses than any other restaurant in Mexico City. A Department of Labor report from the same year surveyed different restaurants, cantinas, and cafeterias located in seven districts in the capital. The report counted the waitstaff in each establishment and listed if they were unionized or non-unionized laborers. Under the listing for "Restaurant Sanbons' [sic], the report indicated the company staffed 40 nonunionized waitresses (AGN, DTSICT, 1921a). The government inspector who collected the statistical information used clear gender suffixes to describe the sex of the workers throughout the report. Sanborns employed 20 more waitresses than El Fénix and $L a$ Flor de México, two of the leading coffeehouses in the city, and 25 more than Lady Baltimore, a very popular restaurant and ice cream shop located across the street from Sanborns.

The preference that Sanborns management had in hiring working women was, paradoxically, contrary to the labor trends of other major restaurants in Mexico City. Susie S. Porter's analysis of census records observed that a clear division of labor existed where, "men dominated in service jobs in first-class restaurants, while women worked mostly in second-class restaurants (Porter, 2003: 47)". The 1921 Department of Labor report reveals only a partial assessment of the number of women who worked at Sanborns. However, the evidence suggests the company hired exclusively non-unionized women to work at waitresses. It can be reasonably assumed that the other working women employed there were also without union protections.
Without the strength of organized labor and with limited mobility to climb upwards into higher positions at the company, working women at Sanborns faced uncertainties and precarity at their jobs. Article 123 of the Mexico's 1917 Constitution outlined certain labor protections, like the "right to dignified and socially useful employment" that permitted workers to organize unions and occasionally go on strike. Article 123 also stipulated a minimum wage sufficient for a laborer to support a family, a day of rest per week, and 20 days of paid vacations per year (Weis, 2012: 110). Yet, for working women at Sanborns, the boundaries between their rights as workers and their everyday working conditions were nonaligned. It remains unclear whether working women received any form of non-wage benefits for their continued employment and acquiescence to the company's labor paternalism. Women who performed well at their jobs were rewarded by their managers with continued employment. They demonstrated their loyalty through their dedicated service to the company, and by accepting their subordination to their superiors. However, women were also disciplined based on these same virtues by managers who controlled their position, movement, and right to work. Thus, working women at Sanborns were required to either accept or reject the company's paternalism and the gendered hierarchy that subjected them (Anonymous, 1921b).

On June 16, 1921, the Department of Labor wrote a memorandum to Sanborns warning that their labor policies could potentially incite tensions among their workers. The document reported that the company's labor contracts were "not acceptable" because they infringed on part 22 of Article 123. That particular subsection required companies who dismissed workers without justification to pay indemnity for three months of wages. The Department of Labor learned that Sanborns was in violation of the labor law, suggesting that certain employees may have petitioned directly to the government. The memorandum stated that company owners at Sanborns did have the power to 
dismiss their employees without justification, if necessary, but were bound to fulfill their labor contracts they had signed or provide the required 90-days of wages. The letter forwarded to the company asserted that Sanborns was actively "trying to avoid compliance with some of the constitutional precepts that favor the labor class" and said that the policy itself "could create a feeling of hostility" which could lead to potential labor conflicts (AGN, DTSICT, 1921b). A few days later, company owners responded to the government, writing that their "objective is not to violate the laws, nor harass our employees; we only want to avoid difficulties and damages (AGN, DTSICT, 1921c)". The terse response indicated that Sanborns at least acknowledged the government's position and understood that the labor contract they signed with employees required them to abide to Mexican law.

The Department of Labor memorandum suggests that Sanborns employees worked in a potentially precarious labor environment. Working women at Sanborns were especially vulnerable considering their employer was a foreign merchant that ran a business not considered a strategic industry (Lear, 2001: 229). Working women at Sanborns may have lacked guarantees of future employment and risked losing their jobs all together without warning or justification, and that they might not receive their 90-day severance as required by Article 123 of the 1917 Constitution. Evidence shows that even if employees went and filed lawsuits against Sanborns, the company hired powerful lawyers that defended themselves against any litigation in the Mexican court system (AGN, TSJDF, 1918). The Department of Labor's warning to Sanborns foreshadowed a large-scale labor protest involving Mexican bakers that occurred exactly a year after the memorandum was written.

\section{Striking Bread Workers Confront Sanborns Paternalism}

In the 1920s, Sanborns was surrounded by protracted labor conflicts and political tur- moil that engulfed downtown Mexico City. Sanborns and its location inside the landmark House of Tiles became a focal point for social criticism that revealed tensions concerning its close association with U.S. capitalism and exclusive appeal to Mexican elites. After all, the House of Tiles once headquarters the Casa de Obrero Mundial, (House of World Workers), an anarcho-syndicalist group that promoted the rights of workers (Lear, 2001: 233). The tense political landscape of Mexico City somehow did not seriously impact the Sanborns business. Evidence shows that the Sanborn brothers attempted to create a retail environment free from the revolutionary politics that surrounded the store. The owners forbade Sanborns employees from talking about politics and apparently the same policy applied to guests who entered the store (Scully, 1942: 10).

On June 16, 1922, telephone operators, textile workers, streetcar workers, electricians, and candymakers, marched in solidarity with a large group of striking bakers in downtown Mexico City (Anonymous, 1922b). The workers had recently left the Regional Confederation of Mexican Workers (CROM) and formed the General Confederation of Workers (CGT) (Weis, 2012: 115-116). The large cross segment of striking workers were an emblematic display of the continued labor struggles and class negotiation that took place after the Mexican Revolution (Weis, 2009). The protests were part of a lengthy labor battle that pitted business owners backed by the police against radicalized bread workers who demanded higher wages, shorter shifts, and medical benefits (Weis, 2012). The strikes disrupted non-unionized establishments, and temporarily paralyzed the city.

At approximately $3: 30 \mathrm{pm}$, a group of fifty male bakers entered Sanborns in the House of Tiles and unfurled red and black strike flags. They deliberately entered Sanborns during the busy lunch hour, when the salon was likely packed with aristocratic guests. The protestors demanded that female waitresses, cooks, and kitchen assis- 
tants abandon their posts, walk of the job, and join the ongoing strike. Panic erupted among the dining customers who fled Sanborns thinking that the protestors were part of an ongoing rebellion. The bakers moved through the dining salon towards the kitchen and tried removing the female bakers working there (Anonymous, 1922a). Sanborns managers immediately called the police. The New York Times reported that a police squadron armed with rifles arrived, surrounded Sanborns, and were given orders to disburse the unruly crowd. It was reported that Celestino Gasca, Mexico City's governor, gave the police permission to shoot the bakers in the event of widespread disorder (Anonymous, 1922e: 2). The New York Times report was not hyperbole. In 1922, two separate incidents involving armed police and striking workers resulted in the shooting deaths of at least one police officer and a bakery worker. According to the newspaper La Raza, the police intervention at Sanborns was necessary to "pacify" the "somewhat militant" attitude of the protestors who had succeeded in temporarily halting work production inside Sanborns, and two other well-known cafeterias and pastry shops in the capital (Anonymous, 1922d: 5). The police eventually cleared out Sanborns without major incident using the threat of force.

This incident does not appear within the larger narrative of working-class labor struggles that took place in Mexico City. However, it nevertheless brought into focus the labor practice of Sanborns. The striking bakers and their organizers entered Sanborns because they knew the institution deliberateIy hired non-unionized female workers. In Mexico City, bakeries were predominantly masculine workspaces. Census records from 1922 reveal that of the 44 bakers located in the capital, each establishment employed on average about 22 male bakers, and only 10 bakeries hired any women workers at all. The average maximum daily salary of a male bread worker was $\$ 7.00$ pesos for a nine-hour workday (AGN, 1922). To put that into perspective, in 1922, the price of a Sanborns commercial lunch cost $\$ 2.00$ pesos (ASH, 1922). The scant statistical evidence available on female bakery workers shows they made significantly less money compared to their male counterparts. On average, women earned less than $\$ 3.00$ a day with the minimum salary close to $\$ 1.67$ (AGN, 1922). What is interesting is that Sanborns managers did not consider their store a bakery, even though they produced cakes and pastries (Anonymous, 1922c), nor did Government inspectors include Sanborns in their 1922 census report of bakeries operating in Mexico City.

The striking male bakers likely perceived Sanborns's paternalism as a threat to their own individual livelihoods. Sanborns directors deliberately instituted a labor system that preferentially hired non-unionized working-women. Women workers earned less wages than men and their lack of affiliation with outside labor movements meant they were easier to control. Their labor position was further weakened under Sanborns's gendered hierarchy of U.S. managers, and by the fact their employer was a foreign merchant not considered in a strategic industry (Lear, 2001: 229). This hiring practice was likely implemented as a defensive measure to insulate the family-owned U.S. company from the wave of revolutionary labor movements that surrounded Mexico City (Snodgrass, 2003: 54-62).

The protesting bakers also entered Sanborns because they knew the store held important social significance as an institution that catered exclusively for Mexico City's powerful upper-class. They used the store as a stage to symbolically contest a public site of power and bring attention to larger systematic labor struggles. The public demonstration followed the precedent established by labor movements during the Mexico Revolution, that attempted to reclaim spaces for the working-class inside Mexico City's opulent downtown neighborhood (Lear, 2001: 233). As Excélsior noted, the decision to protest in Sanborns, "made the scandal much bigger and vastly exaggerated its significance (Anonymous, 1922a)". 


\section{The Sanborns Waitress Uniforms}

From the moment that Sanborns moved into the House of Tiles, the uniforms worn by Sanborns waitresses became important visual markers used by social commentators to describe the boundaries separating the gender, class, and race positions between upper-class guests and the working-women who served them. In 1919, the Mexican writer Armando de Maria y Campos described Sanborns as a "Iordly mansion" filled with distinguished guests packed together in cloth-lined booths being served by young Sanborns waitresses. "In the midst of the atmosphere of originality and good taste, it is shocking that the lady waitresses are uniformed in those insipid and discolored gowns", he said. De Maria y Campos joked that Sanborns managers should instead dress them like pajecillos (servants for the king), "with stockings striped with red or white, gold or green, and colorful wigs" (de María y Campos, 1919). In 1924, Salvador Novo lamented his displeasure for some of the physical changes that Sanborns made to the House of Tiles. He deplored the addition of a glass ceiling, the chessboard floor tiles, the paintings of peacocks on the walls, and the "wet nurse uniforms of those who serve us the medicinal ice creams" (Novo, 1924: 33). These forms of social criticism linked the presence and physical appearance of working-class female employees among the scenery and the modernist transformations found inside the store. They also show that the uniforms worn by Sanborns waitresses became identifiable symbols representing the company.

Beginning in the 1930s, Sanborns directors systematically adjusted their business to evolve within Mexico's changing economic conditions and the intense wave of nationalism that followed the Mexican Revolution (1910-1920). Sanborns directors Mexicanized their stores to increase their customer base beyond local elites and to promote foreign tourism (Chrisman, 2018: 132). Some of the changes made to the stores in Mexico City and Monterrey inclu- ded Mexican artwork and upholstery, restaurant menu items that featured corn dishes associated with Mexico's national cuisine, and a redesigned folkloric uniform which mixed together a selected appropriation of gendered clothing worn by indigenous women in Mexico.

According to a Sanborns manager (Gudiño, 2015), inspiration for the new uniforms was drawn from the clothing typically worn by indigenous women in states that were, "the most generally representative of Mexico". The uniform consisted of three parts that included the huipil de mezcla, the traditional blouse from Puebla, a "modern, bright and comfortable" long striped skirt known as amarres from Oaxaca, and the cap from Nayarit. This highly selective amalgamation of indigenous dress used for the Sanborns uniform shares interesting similarities with the choice of clothing used in other largescale cultural projects of Indigenismo and Mestizaje in postrevolutionary Mexico. As Natasha Varner (2020: 10) shows, this choice of clothing held a set of codes and characteristics that defined what it meant to be an "authentic" indigenous woman.

\section{Photo 1 \\ A Sanborns waitress attends a group of men in the tea salon at the House of Tiles.}

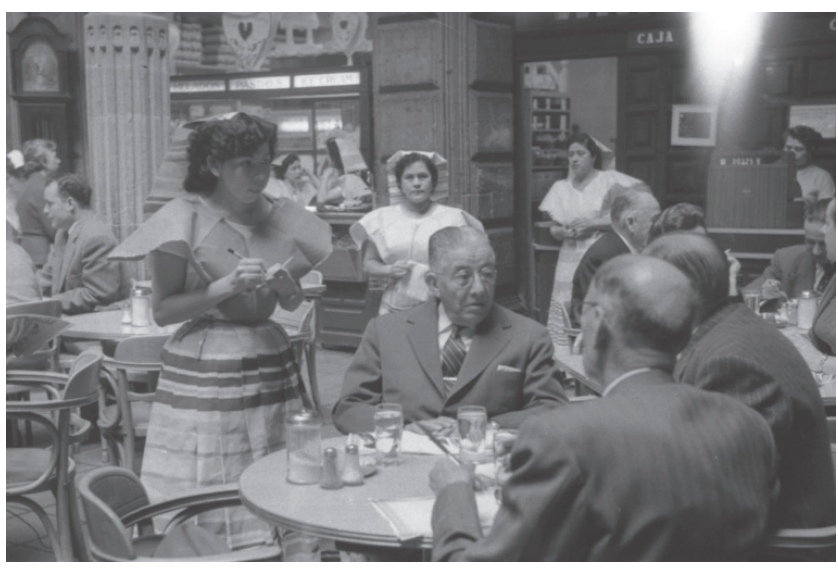

Source: AGN (s.f.).

Foreign visitors may have recognized the uniforms as tropes representing Mexico's indigeneity. One U.S. traveler described a scene within the House of Tiles, which con- 
tained "a beautiful glassed-in patio, where the waitresses are dressed in picturesque native costumes" (Shorr, 1946). Another account lauded the Sanborn brothers for their "real contribution to Mexican culture", in having renovated the House of Tiles with the correct columned patio walls, where the "waitresses were uniformed in the gay Tehuantepec Indian costume" (Scully, 1942: 10). Interestingly, the clothing worn by the Tehuantepec were not one of the groups that Sanborns had molded their uniform from, indicating that customers may have interpreted the cultural constructions differently. In Mexico, Rodolfo Usigli's (2015) classic novel, Ensayo de un Crimen, describes the everyday life of Mexico's upper-class in the 1940s. In one scene inside Sanborns, the protagonist finds a table in the center of the dining salon where he witnesses a group of waitresses "whispering to each other in their fake aboriginal outfits". Carlos Fuentes' novel La cabeza de la hidra (1985) begins with a scene inside Sanborns where the author describes an approaching waitress as "disguised as an Indian".

The racially loaded words "Indian" and "native" imply a set of interrelated issues involving racial and class connotations associated with Mexico's poor rural communities. What these above examples have shown is how the Sanborns uniform encoded the bodies of waitresses with a gendered and racialized meaning, one grounded in a romanticized vision of Mexico's indigenous past.

The addition of the new folkloric uniforms at Sanborns further integrated working women under the company's paternalism and its gendered labor hierarchy. The uniform further controlled their bodies and reinforced their subordinate race and class positions within their workspace. These new uniforms eventually became standardized and experienced very few alterations over the next 80 years.

\section{Working at Sanborns Monterrey: The Case of Alejandra Molina, 1944-1945}

By the time Sanborns Monterrey opened on July 16, 1936, the famous U.S. owned business had been operating for a third of a century. The new branch store marked the company's first successful expansion outside of Mexico City. Company owners tried duplicating their success by exporting a similar business model to Monterrey that included the preferential hiring of workingclass women. Store owners also specificaIly purchased a building along a prominent thoroughfare in Monterrey's downtown business district (Anonymous, 1935: 1). By the 1940s, Monterrey's industrial economy was booming. Rapid industrialization brought an influx of migrants into the capital in search of jobs, and Monterrey's population doubled to over 350,000. During this transformative period, Sanborns Monterrey became an important social institution for both upper-class regios and the influx of foreign tourists visiting Mexico from the United States, some who arrived by automobile on the newly completed Pan-American highway. However, behind the landscape of industrial progress, Monterrey also experienced severe economic hardships following the post-war period as inflation and food shortages pushed real wages to historic lows. These social tensions manifested in a proliferation of anti-government protests, hunger marches, and riots. By 1944, union movement paralyzed Monterrey, as workers protested for improved labor conditions and higher wages (Snodgrass, 2003: 289).

In 1944, Alejandra Molina started working the second shift as a soda fountain waitress in Sanborns Monterrey. For an unskilled female laborer working in the retail sector, the position was considered a good job, especially at a place as prestigious as Sanborns (AGENL, JLCA, 1946a). Women who wanted to become a waitress at Sanborns usually started in the kitchen as either a dishwasher or as an assistant doing miscellaneous labor under the observation of a manager. According to a Sanborns waitress, managers graded worker performance and 
kept detailed records in the office determining whether employees could enter better positions (Gutiérrez, 2018). From behind the lunch counter, Alejandra served customers coffees, sandwiches, ice cream, pastries, shakes and sodas (Anonymous, 1940). Her job required her to bus tables, clean the stoves, wash the windows, and attend the duties required by her bosses. Of the 110 employees who worked at Sanborns Monterrey, 98 were women, or $89 \%$ of the total workforce (AGENL, JLCA, 1947a) Waitresses who worked the dining hall earned the same salary as those who worked the soda fountain (AGENL, JLCA, 1947b). However, they likely received more tips based on the sheer number of tables and clients they waited on. The dining hall was much larger, seated more people, and provided a full menu, unlike the soda fountain which had limited seats along the bar, offered a limited menu of snacks and refreshments, and did not offer the food served from the dining hall (AGENL, JLCA, 1946b). Alejandra and other soda fountain waitresses worked six days a week and rested on Sundays when that department was closed. The restaurant, cocktail lounge, tearoom, and store remained open during normal business hours of 7:30am - 9:30pm. Sanborns Monterrey was an air-conditioned which meant that staff worked in a relatively comfortable workspace. This amenity was probably important considering the sweltering heat notorious to life in Monterrey. Alejandra earned $\$ 108.00$ pesos a month. To put her monthly salary into perspective, an order of comida corrida at Sanborns in 1947 cost $\$ 6.50$ (Anonymous, 1947c). Alejandra's job provided an additional economic incentive in the form of tips from her customers. Tips were deposited into a safe box kept by the cashier and could only be collected by employees who earned them (AGENL, JLCA, 1946b). In other words, tips were not distributed equally among laborers. Therefore, the general income of waitresses depended greatly on the generosity of their regular customers who visited. Building relationships with Sanborns customers was an important way in which waitresses earned their living.

On August 23, 1945, Alejandra showed up for work during her regular shift and was met by her store supervisor, Mrs. Bryan, who told her to visit the office of store manager, Mary Francis Williams. When she arrived, Williams told Alejandra she would be transferred from her position at the soda fountain into the kitchen. The manager assured Alejandra that the change would be temporary. According to Alejandra, on her first day working the kitchen, she washed "thousands of plates" by hand because the dishwasher was broken. She and another colleague then lifted the plates and put them away. That night, Alejandra did not end her shift until midnight (AGENL, JLCA, 1946C). The strenuous labor conditions in the kitchen took a physical toll on her. After a few more days working there, Alejandra visited a doctor and later explained to Williams that she could not endure kitchen work anymore and wanted her old job back. Williams, however, responded that her only options were to stay in the kitchen or leave the company altogether. Alejandra's position at the soda fountain was already filled by another female worker (AGENL, JLCA, 1946d). The decision by management amounted to a demotion at best and mirrored the labor policy candidly described by Frank Sanborn in his speech to the American Chamber of Commerce in 1922. From Alejandra's point of view, the reassignment was unjustified. When she inquired about the reasoning behind the transfer, company management never gave a reason for the removal. On August 26, 1945, Alejandra walked off the job and never returned (AGENL, JLCA, 1946c).

Alejandra filed a lawsuit against Sanborns with the Central Board of Conciliation and Arbitration of the State of Nuevo León a few days after she left Sanborns. Evidence collected during the case included the disposition provided by Alejandra along with testimony from Sanborns employees, managers, and visiting customers. Collectively, the material helps illuminate some of the daily labor conditions of female emplo- 
yees inside Sanborns Monterrey and shows how working women continued to resist the company's paternalism. The arbitration case also raised a litany of questions. Why did Sanborns managers reassign Alejandra? Was it a form of punishment or retaliation? If so, was the punishment enforced because she had been outspoken about some of the company's labor practices? What arguments did the company use to justify her reassignment, and were they legal according to Mexican labor laws? And finally, what do the documents themselves reveal about the condition of labor inside Sanborns Monterrey?

Alejandra's arbitration case focused on two major concerns. The first considered the character and integrity of Alejandra Molina as a Sanborns waitress, and the other focused on the company's labor practices and whether Sanborns managers practiced equitable and just labor policies. Alejandra demanded her position as a soda fountain waitress be reinstated, and that she recovered lost wages due to her firing. Interestingly, Alejandra also demanded she receive wages for her time off, and for the time she spent eating meals on her break. This suggested that Sanborns did not pay wages for employees who ate their meals on their shift. According to Williams' testimony (AGENL, JLCA, 1946d), soda fountain waitresses could eat during their shift, but the company did not feel obligated to pay them. Employees who worked in the dining salon and kitchen received pay while eating during their break. Alejandra felt Sanborns did not provide employees at the soda fountain with the same labor standards as employees in other positions.

During the arbitration hearing, Sanborns managers argued that Alejandra's customers made repeated complaints against her to the cashier and store managers (AGENL, JLCA, 1946e). They contended that she treated her customers rudely, arrogantly, and did not serve them properly. Sanborns brought female workers from the kitchen and a cashier to testify about Alejandra's poor service to customers. Yet, none of the witnesses that testified, including a manager who supposedly received the complaints, could recall a single detail from those incidents. Managers then focused on Alejandra's character as a pretext for reassigning her to the kitchen and indicated that, "it has been the usual practice to change workers from one department to the other at Casa Sanborns" (AGENL, JLCA, 1946f). This evidence demonstrates that Sanborns owners in Mexico City implemented the same labor practices for their Monterrey store. Monterrey's labor lawyer demonstrated that even if Alejandra provided poor customer service or was rude to her customersas the company claimed, the store manager had unilaterally fired her from her position and prevented her from returning to the job. They argued thatAlejandra's demotion to kitchen duties "was not even remotely the same as her old job, and on the contrary, it was an inferior category". On April 3, 1946, Alejandra won her arbitration case against Sanborns. The company reached a settlement outside of court for $\$ 400.00$ pesos. The agreement stipulated that Alejandra must drop her lawsuit and voluntarily leave the company (AGENL, JLCA, 1946g). It also made clear that Sanborns admitted to no wrongdoing and added they had paid Alejandra punctually for her labor. Company managers likely decided to settle outside of court because the weight of evidence against them in the arbitration case.

Alejandra's arbitration case against Sanborns exposed some of the underlying labor tensions experienced between working women and Sanborns management. Her lawsuit showed that the company's labor policies provided unequal economic benefits for working-class employees. During her year at Sanborns, Alejandra probably witnessed these disparities and complained to her managers that she deserved the same benefits as other waitresses working in the dining salon. Her dismissal from the soda fountain and subsequent reassignment can be viewed as an example of how Sanborns disciplined employees they viewed as disloyal. Sanborns managers likely moved Alejandra to the kitchen as punishment for 
questioning the company's labor practices. The arbitration case also demonstrated how government arbitrators pushed back against Sanborns paternalism and its unjust policies that disadvantaged workers. Ultimately, the government resistance helped negotiate between the corporate labor policies and the worker (Snodgrass, 2003: 283). As this next section shows, mounting tensions created by the company's paternalism and its gendered labor hierarchy ultimately manifested into a massive labor strike organized by women workers at Sanborns Monterrey.

\section{The 1947 Labor Strike at Sanborns Monterrey}

In May 1946, the Sanborn brothers sold their company to Walgreens, a U.S. drugstore chain from Deerfield, IL, for $\$ 2.5$ million (\$12.500.000 pesos) (Anonymous, 1945: 2). Sanborns was Walgreens first foreign acquisition that followed in the largescale trend of post-war corporate expansion in search of larger consumer markets outside of the United States. Walgreens inherited the control of both Sanborns stores and kept in place many of the business ideas, strategies, and management systems created by the original store owners. As a result of the buyout, workers who were part of the company-controlled Union of Employees of Sanborns Monterrey (UESM) signed a new labor agreement that reportedly raised their salaries 30\% and provided other labor concessions (JLCA, AGENL, 1947C). Like most sindicato blancos, or company-controlled unions these labor organizations are almost exclusively oriented towards the position of the company (Vellinga, 1979: 115-116). As a result, not all workers at Sanborns Monterrey felt secure with their labor protections under a company-controlled union. Working women continued to experience tensions with the store manager Mary Williams and the company's paternalistic labor system. Meanwhile, across Monterrey, intense union activity continued during the mid-1940s that included protests and strikes against foreign-owned companies that gathered massive profits at the expense of declining wages (Snodgrass, 2003: 292-295).

On October 20, 1947, a Sanborns employee named María Luisa Flores visited the office of the Conciliation and Arbitration Board of Nuevo León. María was the Secretary General of UESM. She requested that an official from the arbitration board witness an assembly of female workers at Sanborns. During a meeting held inside the patio of Sanborns Monterrey, a labor official met with 44 women workers and heard several grievances about the mistreatment they experienced from the store's manager. One woman named Felicitas Blanco reported that when her mother's illness forced her to miss work, the manager suspended her and replaced her with a new employee. Blanco felt this incident hurt her chances of "climbing the ladder" and advancing in the company (AGENL, JLCA, 1947c).

Social mobility and economic independence were probably the reasons why Blanco sought a job at Sanborns. During the meeting, María Luisa Flores explained that in defending the rights of her workers, she was fired by Williams (AGENL, JLCA, 1947d). The firing of the Secretary General of the company-controlled labor union exposed the virulent anti-labor position of Sanborns managers, and the inherent weakness in collective bargaining within the company union.

Alicia Herrera proposed that the best way of defending themselves and the interests of their jobs was by joining a different union, one that actually provided labor protections for union members. She suggested the Union of Employees of Hotels, Canteens, and Restaurants (UEHCRS), an independent union representing workers across a broad spectrum of establishments and industries in Monterrey. Of the 44 women present during the meeting, 37 voted to enter the independent union. Another four said they would join at a later date. The 44 women represented $40 \%$ of Sanborns's entire workforce (AGENL, JLCA, 1947a). The vote signaled that a significant portion of workers had no confidence in the company-con- 
trolled union and felt vulnerable under the company's paternalistic labor system.

On October 23, 1947, the secretary general of the UEHCRS visited the office of the Central Conciliation and Arbitration Board and presented a strike action against Sanborns Monterrey. The document provided a list of demands by workers that needed to be met before a planned strike set for October 30, 1947. They demanded that Sanborns accept the terms of a new collective bargaining agreement. The petition also stipulated that Sanborns needed to "harmonize" the interests of the company with its workers and offer solidarity with other unions on strike. The union argued that Sanborn offered "meager" salaries to its employees compared to similar restaurants in Monterrey, and that the salaries were insufficient to cover expenses for wage earners and their families. According to the document, wages of the workers should reflect the high economic potential of the company. The union pointed to the company's "enormous profits" and "the fame enjoyed by the commercial position" as a popular tourist destination. These profits may have benefited Sanborns owners the success but did not reflect the real earnings of the workers (AGENL, JLCA, 1947e). The document presented to the arbitration board suggests Sanborns workers recognized that their U.S.-owned employer underpaid them compared with other companies operating in Monterrey. Significantly, many of the demands listed were exactly what Alejandra Molina argued for during her arbitration case a few years earlier, including paid holiday time off, paid lunch breaks, and labor protection against unjust suspensions or separation from their positions.

News of the strike vote caught Sanborns management off guard, and the company appeared unaware that a group of women workers had joined an independent union. Company lawyers decried the demands for a wage increase as "illegal and absurd" and presented as evidence to the arbitration board the collective bargaining agreement signed by workers the year prior. Lawyers also produced a list of signatures by seventy Sanborns workers in the ranks of the company controlled UESM. The statement indicated these employees found it "truly surprising" that an outside union was planning a strike since none of them authorized the motion (AGENL, JLCA, 1947f). The evidence would suggest the majority of Sanborns Monterrey employees remained loyal to the company union and were against the strike.

The labor movement against Sanborns set off a chain of events that exposed the company's fears of having their workforce join a labor organization operating outside of company control. Tensions between the outside union and Sanborns management ran high leading up to the proposed strike date. On October $28^{\text {th }}$, 1947, a labor inspector wrote the arbitration board reporting on worker fears of retaliation and punishment. The inspector warned of evidence suggesting the company planned to coerce workers into voting against the strike. Sanborns managers had prevented workers "from acting freely and spontaneously of their will". The official recommended the strike vote be held within the premises of the Conciliation and Arbitration Board to prevent Sanborns managers from using scare tactics to intimidate employees against voting the wrong way (AGENL, JLCA, 1947g). Sanborns lawyers insisted the strike vote should take place in their store, arguing there was potential risk from outside labor agitators who might pressure workers into voting a certain way. Ultimately, the arbitration board allowed the strike vote to take place at Sanborns. On the eve of the strike vote, labor inspectors visited Sanborns and found the store closed to the public with company employees locked indoors. The inspectors were denied entry and reported that the workers were either "detained" or kept there for a group meeting. Further testimony by workers revealed that employees were locked inside the store as early as 3:00pm and included workers from the morning shift (JLCA, AGENL, 1947h). Sanborns lawyers denied the claim. 
On October 30, 1947, the strike vote proceeded at Sanborns Monterrey, and two labor inspectors oversaw the tally that took place. The results showed a majority of Sanborns employees voted against the strike, 83-22 (AGENL, JLCA, 1947i). Labor inspectors, however, wrote a scathing report stating that Sanborns managers had imposed "terrible moral and material pressure" on the workers, including their forced confinement in the store the day before. Inspectors specifically pointed out the objectionable behavior of Mrs. Bryan, the U.S. manager, who coerced workers "by means of word and signs". Inspectors concluded that the vote itself was flawed and should not be accepted. They reported that Sanborns was in blatant violation of a number of labor practices and highlighted the mockery of the voting process. According to the reports, 10 employees voted using the names of other workers. The vote count included names of people that did not appear on the list of employees sent prior to the arbitrator's office. Perhaps most appallingly, the names of Sanborns store managers appeared among the vote tallies, effectively rendering the entire vote as flawed. The vote tally also included the daughter of the Sanborns floor supervisor, Mrs. Bryan who obviously voted against the strike. Collectively, this evidence exposed the total lack of impartiality in the voting process. According to labor inspectors who witnessed the vote, Bryan intimidated workers by standing just a few feet away from where they cast their vote. Ironically, Sanborns lawyer agreed that workers were in fact victims of coercion, but due to the presence of the government inspectors and members from the outside union who supposedly encouraged workers to vote in favor of the strike (AGENL, JLCA, 1947j). The inspector reports reveal that working women experienced intimidation and hostility from company managers who pressured them to vote against the strike. Fearing the consequences of voting the wrong way probably weighed heavily on their vote. Women risked serious repercussions in the event the vote failed, such as possible retaliation, punishment, or termination from the company.

The inspector report on the labor vote offered a conflicting summation. On one hand, they documented Sanborns actively interfered with the voting process and intimidated workers against voting for the strike. The report then summarized incidents showing the strike vote was deeply flawed. Yet, despite all this, the inspectors ultimately concluded that the results should be accepted, arguing that despite the impartiality, voter intimidation, and pressure imposed by the managers, the workers still had the right to vote any way they wanted (AGENL, JLCA, 1947j). Not surprisingly, representatives from the independent union did not recognize the strike vote as legitimate and took issue with the assessment of the labor inspectors who had reluctantly accepted the results. By November 3, 1947, the independent union declared they would not give up their labor strike against Sanborns (AGENL, JLCA, 1947k).

On November $8^{\text {th }}, 1947$, a group of 40 people including members of UEHCRS entered Sanborns Monterrey and occupied the main dining hall. Mexican families eating their lunch watched on as the protestors sat at the tables and demanded service. While sitting around the tables, protestors ordered food they did not eat, smoked cigarettes, and flicked their ashes on the tables. A detachment of uniformed police showed up to prevent disorder. El Porvenir (Anonymous, 1947b) reported that a similar event had occurred just days before. During the incident, 24 waitresses from Sanborns met outside the store holding strike flags accompanied by a group of garbage men who were "especially chosen for their dirty and repugnant appearance. María de Jesús de la Fuente de O'Higgins, a frequent customer of Sanborns Monterrey, recalled the incident during a 2014 interview. According to O'Higgins, she arrived at Sanborns and encountered leaders from the UEHCRS along with garbage collectors sitting at the tables in the restaurant. "Imagine with the temperature of Monterrey how awful they 
smelled”, she said (Cruz Bravo et al., 2014). O'Higgins noticed many candles in the restaurant since the power was turned off, suggesting that Monterrey's electrical workers may have participated in a sympathy strike.

The strike and subsequent occupation of the Sanborns dining hall by people described in the press as street beggars, and "dirty and disheveled individuals" challenged the company's paternalism by disrupting the subordination of working-class women.

The protest continued for months and caused sustained economic damages to the company and its workers. Union representatives refused to meet Sanborns's legal representatives within the office of the Conciliation and Arbitration Board and stalled talks. The government appeared to have tacitly allowed the strike to continue against Sanborns by approving five requests for rescheduled meetings between November $8^{\text {th }}$, 1947, and January 8, 1948 (AGENL, JLCA, 1947I). The maneuver allowed the strike to continue indefinitely, causing significant financial loss and damage against Sanborns's reputation as customers abandoned the store. The prolonged strike reduced the wages of waitresses by more than $80 \%$ as U.S. tourists decided to spend their money elsewhere (Anonymous, 1947a: 10). As John Lear argues (2001: 223-226), these type of workplace occupations of restaurants shaped the collective identities of working people. Their presence in opulent sites of leisure challenges the social meaning of establishments and brought attention to labor conflicts.

In an interesting turn of events, representatives from the independent union visited Mexico City to enter direct talks with Sanborns Mexico and the office of the Governor of Nuevo León. These talks ultimately produced a compromise that ended the protracted labor dispute. The independent union bypassed the authority of both Sanborns Monterrey and the Conciliation and Arbitration Board of Nuevo León.

The maneuver effectively removed Sanborns Monterrey's management from the la- bor discussions and muted them from having a voice in the terms of agreement (AGENL, JLCA, 1947m). Finally, on January 8, 1948, the labor strike against Sanborns Monterrey ended.

It remains unclear whether labor compromises were made to the workers at Sanborns Monterrey. The strike itself was barely reported in local newspapers, and the arbitration documents do not mention what concluded the prolonged labor movement against the company. However, the 1947 labor strike exposed what some of the everyday labor experiences were for a gendered workforce comprised almost entirely of working women. Sanborns paternalism created tensions and anxieties in the workspace. Without support or protections from the company controlled Sanborns union, working women at Sanborns felt vulnerable and routinely experienced violations against their labor protections by U.S. managers. Some women rejected the company's paternalism by mobilizing themselves and by participating in labor action against the company.

Despite the active role of rank-and-file women workers participating in the labor movement against Sanborns, the arbitrators, company lawyers, union representatives, and government officials who oversaw the union decisions were all men. This showed that working women remained marginalized by male decision-makers. Nevertheless, working women at Sanborns expressed their power by using Sanborns as a stage to protest, organize, and improve their labor conditions.

The embarrassing spectacles at Sanborns Monterrey brought public attention to the unjust labor practices at the store. Working women challenged their subordinate position under Sanborns's paternalistic labor system by inviting other socially marginalized people into the dining hall. This sharpened into focus the wide economic gap that separated the upper-class customers from the gendered workforce at Sanborns. 


\section{Conclusion}

This work highlights some of the everyday labor conditions of working women in the retail sector in Mexico City and Monterrey from 1920-1948. It shows that Sanborns adopted a paternalistic labor system to manage its predominantly female workforce. A gendered hierarchy further subordinated women under the company's upper management who were white U.S. born citizens. Women workers at Sanborns rejected Sanborns paternalism. Sometimes they were motivated into action through the eruptions of fellow employees, the presence of outside labor movements, or by the outbursts of visiting customers. Sanborns directors likely structured their labor system as a defensive tactic to insulate themselves from a wave of revolutionary unionism that followed the Mexican Revolution. As Sanborns grew in popularity, the company provided ample opportunities for non-unionized workingclass women to fill a variety of positions inside the store. During their daily work experiences, women navigated around gender and class distinctions that separated them from their upper-class customers and their bosses. Without union protection, women worked in a precarious labor environment and faced potential punishment and possible dismissal by their managers. The company's paternalistic system attempted to mold an obedient and docile workforce. In 1922, a group of CGT bread workers temporarily occupied Sanborns. The protest incident was an emblematic display of labor power directed against the company's labor policies that subjugated non-unionized working women. The CGT bakers used Sanborns as a stage to bring attention to their own working-class struggles for improved labor conditions in Mexico City.

Since 1919, Sanborns waitresses became the focal point for how people visualized and defined class and race positions between upper-class guests and the working women who served them. Beginning in the 1930s, Sanborns introduced a new folkloric uniform that combined a highly selective appropriation of gendered clothing based on Mexico's indigenous populations. The uniform further integrated working women under the company's paternalism, as women's bodies became encoded with a racialized meaning that reinforced their subordinate position within their workspace. 90 years after its introduction, this uniform is now synonymous with Sanborns and an easily identifiable symbol that all Mexicans surely recognize. In 1936, Sanborns opened a branch store in Monterrey. Company owners implemented the same labor strategy of hiring working women to fill a variety of store positions and hired U.S.-born citizens as store managers. The company preemptively organized its workers under a company-controlled union in the context of the pro-union national climate of the 1930s1940s. However, the combination of these labor policies created tensions among working women at Sanborns who felt increasingly vulnerable in their workspace. Working women rejected Sanborns paternalism by filing lawsuits against the company, organizing themselves, and by going on strike. The 1947 labor strike against Sanborns Monterrey caused sustained economic damage and public embarrassment to Sanborns. A relative calm of labor activism following the strike suggests that Sanborns directors modified their company's paternalism and expanded non-wage benefits to the workforce.

\section{References}

\section{Archival Material}

AGENL (Archivo General del Estado de Nuevo León) (1946a), "Asunto: Alejandra Molina contra Casa Sanborn's Monterrey", 28 de agosto de 1945 al 3 de abril de 1946, Junta Central de Conciliación y Arbitraje del Estado de Nuevo León (hereafter JLCA), caja 341/6.

AGENL (Archivo General del Estado de Nuevo León) (1946b), "Luis Pérez Salinas, testigo presentado por la actora", 11 de octubre de 1945, Junta Central de 
Conciliación y Arbitraje del Estado de Nuevo León, caja 341/6.

AGENL (Archivo General del Estado de Nuevo León) (1946c), "La confesión de la señorita Alejandra Molina”, 11 de octubre de 1945, Junta Central de Conciliación y Arbitraje del Estado de Nuevo León, caja 341/6.

AGENL (Archivo General del Estado de Nuevo León) (1946d), "Confesional ofrecida por la Señora Francisca $H$. de Williams y protestada como corresponde para que se condujera con verdad, contestó a las posiciones que le fueron articuladas verbalmente por el señor José Vildózola representante de la demandante", 15 de diciembre de 1945, Junta Central de Conciliación y Arbitraje del Estado de Nuevo León, caja 341/6.

AGENL (Archivo General del Estado de Nuevo León) (1946e), "Testimonio de Sra. Margarita Brayn [sic]", 15 de diciembre de 1945, Junta Central de Conciliación y Arbitraje del Estado de Nuevo León, caja 341/6.

AGENL (Archivo General del Estado de Nuevo León) (1946f), "Alberto Margáin Zozaya, abogado por Sanborns, carta por los miembros del grupo especial No. Tres de la H. Junta Central de Conciliación y Arbitraje", 17 de diciembre de 1945, Junta Central de Conciliación y Arbitraje del Estado de Nuevo León, caja 341/6.

AGENL (Archivo General del Estado de Nuevo León) (1946g), "Carta de Lic. Alberto Margáin Zozaya, Abogado de la Casa Sanborns Monterrey", 3 de abril, Junta Central de Conciliación y Arbitraje del Estado de Nuevo León, caja 341/6.

AGENL (Archivo General del Estado de Nuevo León) (1947a), "Document signed by F. Williams, manager, Lista de Empleadas y Empleados de Sanborns Monterrey, S.A", 28 de octubre, Junta Central de Conciliación y Arbitraje del Estado de Nuevo León, caja 392, exp. 10.
AGENL (Archivo General del Estado de Nuevo León) (1947b), "Tabulador de Salarios"., 23 de octubre, Unión de Empleados Por La Empresa Casa Sanborn's Monterrey, S.A., exp. 10, caja 392.

AGENL (Archivo General del Estado de Nuevo León) (1947c), "Carta de Lic. Alberto Margáin Zozaya al C. Presidente de la H. CJCA in Unión de Empleados de Hoteles, Cabarets, Restaurantes y Similares de Nuevo León contra Casa Sanborns, Monterrey, S.A. ubicada en Escobedo numero 920 sur cruz con Morelos: por Emplazamiento de Huelga Sobre: Celebración de un Contrato de Trabajo La parte actora se desiste", 3 de noviembre, Junta Central de Conciliación y Arbitraje del Estado de Nuevo León, caja 392/10.

AGENL (Archivo General del Estado de Nuevo León) (1947d), "Tomás Mezquiti Jenz", 20 de octubre, Junta Central de Conciliación y Arbitraje del Estado de Nuevo León, caja 392/10.

AGENL (Archivo General del Estado de Nuevo León) (1947e), "Letter from Isaac Jara Reyna and Nicolas Ramos to Frances Williams, Manager of Sanborn's Monterrey", 23 de octubre, Junta Central de Conciliación y Arbitraje del Estado de Nuevo León, caja 392/10.

AGENL (Archivo General del Estado de Nuevo León) (1947f), "Letter from the Sindicato de Empleados y Empleadas de Sanborns Monterrey to the C. Presidente de la H. Junta Central de Conciliación y Arbitraje del Estado", 22 de octubre, Junta Central de Conciliación y Arbitraje del Estado de Nuevo León, caja 392/10.

AGENL (Archivo General del Estado de Nuevo León) (1947g), "Isaac Jara Reyna, Secretario General de la Unión de Empleados de Hoteles, Cantinas, Restaurants y Similares a los Integrantes del Grupo Especial Número Dos", 28 de octubre, Junta Central de Conciliación y Arbitraje del Estado de Nuevo León, caja 392/10. 
AGENL (Archivo General del Estado de Nuevo León) (1947h), "Reportaje de los Representantes que integran el Grupo Especial Número Dos", 31 de octubre, Junta Central de Conciliación y Arbitraje del Estado de Nuevo León, caja 392/10.

AGENL (Archivo General del Estado de Nuevo León) (1947i), "Alberto Margáin Zozaya, carta por los Miembros del Grupo Especial No. 2", 31 de octubre, Junta Central de Conciliación y Arbitraje del Estado de Nuevo León, caja 392/10.

AGENL (Archivo General del Estado de Nuevo León) (1947j), "Porfirio M. Díaz, El C. Inspector del Trabajo, reportaje al H. Grupo Especial No. 2 de la Junta Central de Conciliación y Arbitraje del Estado", 30 de octubre, Junta Central de Conciliación y Arbitraje del Estado de Nuevo León, caja 392/10.

AGENL (Archivo General del Estado de Nuevo León) (1947k), "Carta de Isaac Jara Reyna y Nicolás Ramos por al C. Presidente de la H. Junta Central de Conciliación y Arbitraje del Estado", 3 de noviembre, Junta Central de Conciliación y Arbitraje del Estado de Nuevo León, caja 392/10.

AGENL (Archivo General del Estado de Nuevo León) (1947l), "Alberto Margáin Zozaya manifestó que no está conforme ni acepta la prórroga concedida por este H. Grupo a los dirigentes de la Unión para que el Movimiento de Huelga estalle del día ocho de Enero", Junta Central de Conciliación y Arbitraje del Estado de Nuevo León, caja 392/6.

AGENL (Archivo General del Estado de Nuevo León) (1947m), "Grupo Esp. Núm. 2", 8 de enero, Junta Central de Conciliación y Arbitraje del Estado de Nuevo León, caja 394/10.

AGN (Archivo General de la Nación) (s.f.). "A Sanborns waitress attends a group of men in the tea salon at the House of Tiles. Hermanos Mayo", Cafeteria Sanborns de México, Calle Madero. Hermanos Mayo, Cronológico, Sobre 7644, Tira 4. Fototeca, Mexico City.
AGN (Archivo General de la Nación) (1918), "Ceuppens, Hector, Juicio Ord. Merc. Contra Sanborns Bross, Sucrs.", 12 de octubre, Tribunal Superior de Justicia del Distrito Federal (TSJDF), caja 1511, folio 269988.

AGN (Archivo General de la Nación) (1921a), "Datos sobre empleados de Restaurante", 14 de noviembre, Departamento del Trabajo, Secretaria de Industria, Comercio y Trabajo (DTSICT), caja 294/25.

AGN (Archivo General de la Nación) (1921b), "El jefe de Sección de Legislación dice no es aceptable el contrato de Srs. Sanborn's Hermanos, Sucs. Porque infringe fracción XXII del artículo 123 Constitucional", 16 de junio, Departamento del Trabajo, Secretaria de Industria, Comercio y Trabajo, caja 303/2.

AGN (Archivo General de la Nación) (1921c), "Francis Sanborn a Al C. Oficial Mayor de la Secretaría de Industria, Comercio y Trabajo", 20 de junio, Departamento del Trabajo, Secretaria de Industria, Comercio y Trabajo, caja 303/2.

AGN (Archivo General de la Nación) (1922), "Estadística. Censo Industrial. Expediente de todas las panaderías existentes en el D.F. Secretaría de Industria, Comercio y Trabajo", julio de 1922 - enero de 1923, exp. 3, caja 412.

AHCM (Archivo Histórico de la Ciudad de México) (1921), "Diversiones públicas", Fondo Ayuntamiento y Gobierno del Distrito, vol. 808, exp. 1412.

ASH (Archivo Sanborn Hermanos) (1939), "Sanborns Souvenir", Sanborns Booklet.

ASH (Archivo Sanborn Hermanos) (1922), "Commercial Luncheon", 27 de agosto, Programa Musical Cuarteto Sanborn.

\section{Bibliography}

Anonymous (1921b), "El Banquete en la Cámara Americana de Comercio", El Universal, 22 de septiembre, Mexico City. 
Anonymous (1921a), "Inauguration of Sanborn's Te Dansant Tomorrow," The Mexican Post, 11 de agosto, Mexico City.

Anonymous (1922a), "La Huelga de Tranviarios Tiende a Prolongarse por no Llegar a Ningún Acuerdo", Excélsior, sábado 17 de junio, Mexico City, pp. 1-5.

Anonymous (1922b), "El Gobierno Impartirá Las Garantías Constitucionales a Los Obreros Libres", El Universal, 17 de junio, Mexico City, pp. 1,9.

Anonymous (1922c), "Gloomy Prospects for a Strike Settlement Soon", Excélsior, Saturday 17, Mexico City.

Anonymous (1922d), "Entre Gendarmes y Huelguistas se registró Ayer Sangriento Encuentro", La Raza, 17 de junio, p.5.

Anonymous (1922e), "Restaurant Guards Used in Mexico City", New York Times, June 17, New York, p. 2.

Anonymous (1924), "A Business that Became a Social Institution", The American Exporter, (95), p. 35.

Anonymous (1935), "Sanborns of Mexico to Open Here", El Porvenir, 8 de diciembre, Monterrey, Sección 2a, p. 1.

Anonymous (1945), "Poderosa Empresa Droguera Compró Sanborn de México", El Nacional, 28 de mayo, Mexico City, p. 2.

Anonymous (1947a), "Pidieron Garantías Al GBNO. Los Empleados del Sanborn's", El Porvenir, 4 de diciembre, Monterrey, p. 10.

Anonymous (1947b), "Siguen Saboteando a la Casa Sanborn's los Sindicalizados", El Porvenir, 8 de noviembre, Monterrey, p. 19.

Anonymous (1947c), "Sanborns Restaurant Menu. Mexico City, Mexico", Sanborns ephemera, personal archive.

Anonymous (1940), "Sanborns Monterrey México", Company souvenir booklet, personal archive.
Barrios Gómez, Agustín (1994), "La Casa de los Azulejos", El Informador, 28 de agosto, Guadalajara p. 5-A.

Chrisman, Kevin M. (2018), "Meet me at Sanborns: Labor, Leisure, Gender and Sexuality in Twentieth Century Mexico", PhD Dissertation, York University, Toronto.

Cruz Bravo, P., Martínez, C., Hernández Garza, M. (2014), "María de Jesús de la Fuente Casas de O'Higgins", Memoria Universitaria: Boletín del Centro de Documentación y Archivo Histórico de la UANL, 5 (48), Monterrey, Universidad Autónoma de Nuevo León.

De María y Campos, Armando (1919), "La Vida en México", Mefistófeles, 13 de octubre, Mexico City, p. 13.

Dowd Hall, J., Leloudis, J., Korstad, R., Murphy, M., Jones, L.A. (1987), Like a Family: The Making of a Southern Cotton Mill World, Chapel Hill, University of North Carolina Press.

Farnsworth-Alvear, Ann (2000), Dulcinea in the Factory: Myths, morals, Men, and Women in Colombia's Industrial Experiment, 1905-1960, Durham, Duke University Press.

Fernández-Aceves, María Teresa (2003), "Once We Were Corn Grinders: Women and Labor in the Tortilla Industry of Guadalajara, 1920-1940", International Labor and Working-Class History, 63, Cambridge, Cambridge University Press.Fuentes, Carlos (1985), La cabeza de la hidra, Mexico City, Editorial Artemisa, S.A.

Gauss, Susan (2010), Made in Mexico: Regions, Nations and the State in the Rise of Mexican Industrialism, 1920s-1940s, University Park, Pennsylvania State University Press.

Hernández, Sonia (2017), "Las cigarreras en la frontera mexicana: trabajo y género en Nuevo León, 1890-1940", in Lylia Palacios Hernández (ed.), Entre montañas y sierras: Resistencia y organización laboral en Monterrey en el siglo XX., 
Monterrey, Universidad Autónoma de Nuevo León, pp. 173-215.

Lear, John (2001), Workers, Neighbors, and Citizens: The Revolution and Mexico City, Lincoln, University of Nebraska Press.

Lobato, Mirta Zaida (1997), "Women Workers in the Cathedrals of Corned Beef: Structure and Subjectivity in the Argentine Meatpacking Industry", in James French and Daniel James (eds.), The Gendered Worlds of Latin American Women Workers: From Household and Factory to the Union Hall and Ballot Box, Durham, Duke University Press, pp. 53-71.

Novo, Salvador (1924), "Sanborn's", El Universal Ilustrado, 3 de julio, p. 33, reprinted in Cuesta, Jorge; Novo, Salvador; Torres Bodet, Jaime; Villaurrutia, Xavier, Los Contemporáneos en El Universal, Mexico City, Fondo de Cultura Económica, 2016.

Palacios, Lylia (2017), "Hilvanando la memoria: el movimiento de obreras en Medalla de Oro (1971-1974)", in Lylia Palacios Hernández (ed.), Entre montañas y sierras: Resistencia y organización laboral en Monterrey en el siglo XX., Monterrey, Universidad Autónoma de Nuevo León, pp. 219-261.

Porter, Susie S (2003), Working Women in Mexico City: Public Discourses and Material Conditions, 1879, 1931, Tucson, University of Arizona Press.

Ramírez Sánchez, Miguel Ángel (2011), "Los sindicatos blancos de Monterrey (19312009)", Frontera Norte, 23 (46), Tijuana, El Colegio de la Frontera Norte, pp. 177-210.

Scully, Michael (1942), “Pan America's Crossroads Store”, The Pan American Magazine, 2.

Shorr, Ethel (1946), "Personal", The Argonaut, Sanborns Hermanos Scrapbook, Archivo Sanborn Hermanos.

Snodgrass, Michael (2003), Deference and Defiance in Monterrey: Workers, Pater- nalism, and Revolution in Mexico, 18901950, Cambridge, Cambridge University Press.

Usigli, Rodolfo (2015), Ensayo de un Crimen, Mexico City, Penguin Random House.

Varner, Natasha (2020), La Raza Cosmética: Beauty, Identity, and Settler Colonialism in Postrevolutionary Mexico, Tucson, University of Arizona Press.

Vellinga, Mennos (1979), Industrialización, Burguesía y Clase Obrera en México: el caso de Monterrey, Mexico City, Siglo Veintiuno Editores.

Weinstein, Barbara (1996), For Social peace in Brazil: Industrialist and the Remaking of the Working Class in São Paulo, 1920-1964, Chapel Hill, University of North Carolina Press.

Weis, Robert (2009), "Immigrant Entrepreneurs, Bread and Class Negotiation in Postrevolutionary Mexico City", Mexican Studies/Estudios Mexicanos, 25 (1), Berkeley, University of California Press, pp. 71-100.

Weis, Robert (2012), Bakers and Basques: A Social History of Bread in Mexico, Albuquerque, University of New Mexico Press.

Wolfe, Joel (1993), Working Women, Working Men: São Paulo and the Rise of Brazil's Industrial Working Class, 19001955, Durham, Duke University Press.

Zarebska, Carla (1999), La Casa de los Azulejos, Mexico City, Sanborns.

\section{Interviews}

Gudiño, Brenda (2015), entrevistada por Kevin M. Chrisman [oral], Mexico City, Mexico, julio 9.

Gutiérrez, María (2018), entrevistada por Kevin M. Chrisman [oral], Acapulco, Guerrero, Mexico, junio 8. 
Received: October 13, 2021. Accepted: December 8, 2021. Published: January 27, 2022.

\section{Kevin Chrisman}

Is a Research Associate at the Centre for Research on Latin America and the Caribbean (CERLAC) at York University, Toronto (Canada). He is a cultural historian of modern Mexico who focuses on the topics of gender, urban sexuality, transnational history and the history of capitalism. In 2019 he earned his Ph.D. in Latin American History at York University writing a dissertation titled, "Meet me at Sanborns: Labor, Leisure, Gender and Sexuality in Twentieth-Century Mexico". He is the recipient of the 2019 Canadian Association for Latin American and Caribbean Studies (CALACS) Outstanding Dissertation Prize. His book project examines the complicated relationship between U.S. capitalism, Mexican gender identities and consumer culture in Mexico through the lens of Sanborns. 